\title{
MENINGKATKAN HASIL BELAJAR SISWA MELALUI PENERAPAN MODEL PEMBELAJARAN INQUIRY PADA SISWA KELAS VI SDN 1 TINUKARI
}

\author{
Karmila $^{1)}$, La Ode Kaimuddin ${ }^{2)}$ \\ 1) SDN 1 Tinukari, Kolaka Utara, Indonesia \\ ${ }^{2)}$ Jurusan PGSD, Universitas Halu Oleo, Kendari, Indonesia \\ email: mila85467@gmail.com
}

\begin{abstract}
Abstrak: Penelitian ini bertujuan untuk meningkatkan hasil belajar siswa melalui pembelajaran Inquiry pada materi pokok daya hantar benda terhadap panas di kelas VI SD Negeri 1 Tinukari. Penelitian tindakan kelas ini dilaksanakan pada semester ganjil, tahun pelajaran 2016/2017 di kelas VI SD Negeri 1 Tinukari Kabupaten Kolaka Utara. Subjek penelitian ini adalah siswa di kelas VI SD Negeri 1 Tinukari yang berjumlah 22 siswa. Faktor yang diteliti dalam penelitian tindakan kelas ini adalah faktor siswa, dan faktor guru. Prosedur penelitian mengikuti prosedur penelitian tindakan kelas yaitu; (a) perencanaan, (b) pelaksanaan tindakan, (c) observasi dan evaluasi, dan (d) refleksi. Hasil penelitian menunjukkan bahwa penerapan metode Inquiry dapat meningkatkan hasil belajar siswa pada materi daya hantar benda terhadap penas pada siswa kelas SD Negeri 1 Tinukari. Hal ini dapat dilihat pada peningkatan hasil belajar siswa, pada siklus I rata-rata hasil belajar siswa adalah 63,64 dengan ketuntasan klasikal sebesar 59,09\% sedangkan pada siklus II rata-rata hasil belajar siswa adalah 77,27 dengan ketuntasan klasikal sebesar mencapai 90,91\%.
\end{abstract}

Kata kunci: hasil belajar; model inquiry

\section{IMPROVING THE STUDENT'S LEARNING OUTCOMES THROUGH THE IMPLEMENTATION OF INQUIRY LEARNING MODELS IN CLASS VI STUDENTS OF SDN 1 TINUKARI}

\begin{abstract}
The aim of the study was improve student learning outcomes through Inquiry learning on the subject matter of the conductivity of objects against heat in class VI SD Negeri 1 Tinukari. This classroom action research was conducted in odd semesters, 2016/2017 school year in class VI SD Negeri 1 Tinukari, North Kolaka Regency. The subjects of this study were 22 students in class VI SD Negeri 1 Tinukari. The factors examined in this classroom action research are student factors and teacher factors. The research procedure followed the classroom action research procedure, namely; (a) planning, (b) implementing actions, (c) observation and evaluation, and (d) reflection. The results showed that the application of the Inquiry method can improve student learning outcomes in the material of the carrying capacity of objects against penas in class students of SD Negeri 1 Tinukari. This can be seen in the increase in student learning outcomes, in the first cycle the average student learning outcomes was 63.64 with classical completeness of $59.09 \%$ while in the second cycle the average student learning outcomes was 77.27 with classical completeness of reaching $90.91 \%$.
\end{abstract}

Keywords: learning outcomes; inquiry model; 


\section{Pendahuluan}

Tujuan pembelajaran IPA secara umum adalah agar siswa memahami konsep IPA dan keterkaitannya dengan kehidupan sehari-hari, memiliki keterampilan tentang alam sekitar untuk mengembangkan pengetahuan tentang alam sekitar, mampu menerapkan berbagai konsep IPA untuk menjelaskan gejala alam dan mampu menggunakan teknologi sederhana untuk memecahkan masalah yang ditemukan dalam kehidupan sehari-hari. IPA merupakan mata pelajaran yang mempelajari peristiwa-peristiwa yang terjadi di alam. Materi IPA di sekolah dasar terdiri atas pengetahuan-pengetahuan alam yang ada disekitar siswa yang diharapkan mampu memberi bekal kepada siswa untuk diterapkan dalam kehidupan seharihari. (Darmawan, dkk. 2017, p.1). Menurut Retno, dkk (2016, p.2) mengemukakan bahwa IPA sebagai kumpulan memiliki makna penemuan IPA dilandasi oleh sikap ilmiah. Membelajarkan IPA di sekolah dasar selain membelajarkan penguasaan produk dan proses juga membelajarkan sikap ilmiah.

Proses pembelajaran menekankan pada pemberian pengalaman langsung untuk mengembangkan kompetensi agar menjelajahi dan mengetahui alam sekitar secara ilmiah. Pendidikan IPA diarahkan untuk perkembangan kognitif dan berbuat sehingga dapat membantu siswa untuk memperoleh pemahaman yang lebih mendalam tentang alam sekitar.

Berkaitan dengan hal tersebut di atas, teori konstruktivisme menjelaskan bahwa dalam proses pembelajaran IPA siswa didorong untuk belajar sendiri secara mandiri untuk mendapatkan pengalaman, dan melakukan Inquiry untuk menemukan prinsip-prinsip bagi dirinya. Keuntungannya adalah membangkitkan keingintahuan dan motivasi siswa untuk bekerja hingga menemukan jawabannya, serta melakukan kegiatan analisis dan memanipulasi informasi untuk dapat memecahkan masalah. Untuk mencapai tujuan tersebut di atas dalam pembelajaran IPA di sekolah dasar perlu memperhatikan pendekatan yang sesuai dengan pembelajaran IPA dan benar-benar mampu meningkatkan hasil belajar siswa. Menurut Ulfah (2016, p.1610) mengemukakan bahwa hasil belajar merupakan hasil keberhasilan dari interaksi belajar mengajar yang mencakup bidang kognitif, afektif, dan psikomotorik yang ditunjukkan dengan perubahan tingkah laku yang khas. Senada dengan Rosidah (2017, p.30) menjelaskan bahwa hasil belajar siswa adalah perolehan hasil yang dicapai siswa dalam usaha belajarnya sebagaimana dicantumkan dalam nilai rapornya.

Berdasarkan hasil belajar siswa dalam mata pelajaran IPA pada materi pokok Daya hantar benda terhadap panas Tahun 2015/2016 rerata hasil ulangan harian adalah 5,8 masih sangat kurang jika dibandingkan dengan Kriteria Ketuntasan Minimal mata pelajaran IPA SD Negeri 1 Tinukari Kabupaten Kolaka Utara yaitu 6,5.

Beberapa faktor yang diduga mempunyai pengaruh terhadap peningkatan hasil belajar IPA, yaitu kurikulum, media, guru, dan proses pembelajaran. Dari faktor-faktor tersebut, proses pembelajaran merupakan faktor yang cukup penting, karena dalam proses itu terjadi interaksi antara guru dengan siswa. Dalam pembelajaran diperlukan kesesuaian antara pengalaman guru dengan siswa. Kebermaknaan pembelajaran IPA sangat ditentukan oleh kegiatan-kegiatan nyata, karena siswa SD belum dapat menghubungkan alasan yang bersifat hipotesis. Pengetahuan tumbuh berkembang melalui pengalaman dan pemahaman akan berkembang semakin kuat apabila selalu diuji dengan pengalaman baru.

Untuk mengatasi rendahnya hasil belajar pada mata pelajaran IPA pada pokok bahasan Daya hantar benda terhadap panas di SD Negeri 1 Tinukari Kabupaten Kolaka Utara, perlu dilakukan penelitian tindakan kelas dengan menggunakan pendekatan dan pembelajaran yang dapat meningkatkan aktivitas dan hasil belajar siswa. Adapun pendekatan yang digunakan salah satunya adalah pendekatan Inquiry. 
Pendekatan Inquiry adalah salah satu pembelajaran yang dikembangkan dalam pendekatan konstruktivisme. Yang dapat mengaktifkan siswa untuk membangun pemahamannya sendiri tentang alam semesta dan lingkungan sekitarnya. Menurut Kunandar dalam Hanifah (2017, p.93) pembelajaran inquiry adalah kegiatan pembelajaran dimana siswa didorong untuk belajar melalui keterlibatan aktif mereka sendiri dengan konsep-konsep dan prinsip-prinsip, dan guru mendorong siswa untuk memiliki pengalaman dan melakukan percobaan yang memungkinkan siswa menemukan prinsip-prinsip untuk diri mereka sendiri. Model pembelajaran inquiry adalah rangkaian kegiatan pembelajaran yang menekankan pada keaktifan siswa untuk memiliki pengalaman belajar dalam menemukan konsep - konsep materi berdasarkan masalah yang diajukan (Suhada, 2017, p.15). Sintagmatik atau struktur model pembelajaran Inquiry menurut Joyce, Weil dan Calhoun dalam Supriyati \& Mawardi (2015, p.85) yaitu: tahap pertama, orientasi atau mengenalkan masalah. Pada tahap ini guru menyajikan situasi permasalahan dan menjelaskan prosedur-prosedur penelitian. Situasi permasalahan dapat disajikan dalam bentuk cerita yang disampaikan secara verbal maupun melalui pertunjukkan suatu percobaan atau sebuah gambar.

Melalui pembelajaran Inquiry ini diharapkan siswa lebih aktif dan terlibat dalam pembelajaran secara optimal. Berdasarkan latar belakang tersebut di atas, peneliti tertarik melakukan Penelitian Tindakan Kelas yang berjudul "Meningkatkan Hasil Belajar siswa pada materi Daya Hantar Benda Terhadap Panas Melalui Penerapan Model Pembelajaran Inquiry pada Siswa Kelas VI SD Negeri 1 Tinukari Kabupaten Kolaka Utara”

Masalah dalam penelitian ini adalah: Apakah penerapan pembelajaran Inquiry dapat meningkatkan hasil belajar siswa pada materi daya hantar benda terhadap panas kelas VI SD Negeri 1 Tinukari Kabupaten Kolaka Utara? Tujuan penelitian ini adalah untuk meningkatkan hasil belajar siswa melalui pembelajaran Inquiry pada materi pokok daya hantar benda terhadap panas di kelas VI SD Negeri 1 Tinukari Kabupaten Kolaka Utara. Penelitian ini diharapkan dapat memberikan manfaat bagi guru, siswa, sekolah dan penelitian lainnya.

\section{Metode}

Jenis penelitian adalah penelitian tindakan kelas (PTK). Penelitian ini dilaksanakan pada semester ganjil tahun ajaran 2016/2017 yang bertempat di kelas VI SD Negeri 1 Tinukari Kabupaten Kolaka Utara dengan subyek dalam penelitian ini adalah siswa kelas VI SD Negeri 1 Tinukari Kabupaten Kolaka Utara dengan jumlah siswa 22 orang. Penelitian tindakan kelas ini dilaksanakan dalam dua siklus yang terdiri dari empat tahapan yaitu perencanaan, pelaksanaan tindakan, observasi dan evaluasi serta refleksi Jenis data dalam penelitian ini adalah data kualitatif dan kuantitatif. Data kualitatif berupa kegiatan proses pembelajaran aktivitas belajar siswa dan aktivitas guru. Data kuantitatif berupa nilai hasil belajar siswa. Sumber data dalam penelitian ini adalah guru dan siswa Kelas V SD Negeri 1 Tinukari Kabupaten Kolaka Utara.

Data kualitatif akan dianalisis secara deskriptif kualitatif berdasarkan observasi, sedangkan data kuantitatif dianalisis secara kuantitatif. Indikator keberhasilan dalam penelitian ini adalah Segi proses pembelajaran dianggap berhasil apabila 80\% dari skenario pembelajaran terlaksana dengan baik. Sedangkan, dari segi hasil pembelajaran dianggap berhasil apabila $80 \%$ dari jumlah siswa memperoleh nilai $\geq 65(\mathrm{KKM})$

\section{Hasil}

\section{Hasil Belajar Siswa}

Berdasarkan analisis data hasil penilaian tes pada siklus I nampak bahwa siswa yang mendapat nilai $\geq 65$ atau tuntas sebanyak 13 orang atau sebesar $59,09 \%$ dan siswa yang mendapat nilai $<65$ atau tidak tuntas sebanyak 9 orang atau sebesar 40,91\%. Hal ini 
menunjukkan bahwa keberhasilan peneliti dalam melaksanakan kegiatan belajar mengajar dengan menggunakan metode inquiry belum mencapai KKM, sehingga masih harus dilanjutkan lagi pada siklus berikutnya. analisis data hasil penilaian tes pada siklus II nampak bahwa siswa yang mendapat nilai $\geq 65$ atau tuntas sebanyak 20 orang atau sebesar $90,91 \%$ dan siswa yang mendapat nilai $<65$ atau tidak tuntas sebanyak 2 orang atau sebesar $9,09 \%$.

\section{Aktivitas Guru}

Aktivitas guru dalam proses pembelajaran mengalami peningkatan dari pertemuan 01 sampai pada pertemuan 02. Pada pertemuan 01 aktivitas guru memperoleh jumlah skor 9 dari 14 aktivitas dengan persentase sebesar 70,00\%.pada pertemuan 02 aktivitas guru memperoleh jumlah skor 10 dengan persentase sebesar 71,43\%. aktivitas guru dalam proses pembelajaran mengalami peningkatan dari pertemuan 1 sampai pada pertemuan 2 . Pada pertemuan 1 aktivitas guru berjumlah 12 dari 14 aktivitas dengan persentase $85,71 \%$. Pada pertemuan 2 jumlah skor aktivitas guru meningkat mernjadi 14 dengan persentase sebesar $100 \%$.

\section{Aktivitas Siswa}

Skor aktivitas siswa yang terlaksana pada pertemuan 1 adalah sebesar 7 aktivitas dari 10 aktivitas dengan persentase sebesar 70,00\%. Pada pertemuan 2 skor aktivitas siswa yang terlaksana meningkat menjadi 8 aktivitas dari 10 aktivitas dengan persentase sebesar $80 \%$. skor aktivitas siswa pada pertemuan 1 berjumlah 9 dengan persentase sebesar 90,00\%. Pada pertemuan 2 skor aktivitas siswa berjumlah 10 dan persentase sebesar $100 \%$.

\section{Pembahasan}

Berdasarkan hasil observasi terhadap aktivitas siswa pada siklus I pertemuan 1 diperoleh skor aktivitas siswa berjumlah 7 dengan persentase sebesar 70,00\%. sedangkan pada pertemaun 2 diperoleh skor aktivitas siswa sebesar 8 dengan presenta sesebesar $80 \%$. Hal ini dikarenakan beberapa aspek aktivitas siswa masih belum terlaksana dengan baik seperti masih ada siswa belum memperhatikan dan menanggapi serta memberikan pertanyaan penjelasan materi pelajaran yang disampaikan, masih ada siswa belum maksimal dalam mengidentifikasi masalah dan menentukan hipotesis yang relevan dengan permasalahan, masih ada siswa belum dapat menentukan langkah-langkah pengamatan sesuai dengan hipotesis, siswa belum maksimal mempresentasikan hasil pengamatan,masih ada siswa belum membuat kesimpulan hasil pengamatan dan bertanya tentang materi yang belum dimengerti, siswa belum maksimal dalam berdiskusi menanggapi pertanyaan serta masih banyak yang belum mampu menyimpulkan materi pembelajaran dengan baik sehingga dapat dikatakan bahwa dalam kegiatan pembelajaran pada siklus I masih terdapat kekurangan yang harus diperbaiki.

Selain itu, kurangnya aktivitas siswa pada siklus I pertemuan 1 dan pertemuan 2 juga dapat terjadi karena aktivitas guru dalam proses pembelajaran belum maksimal. Hal ini dapat terlihat dari perolehan skor aktivitas guru pada pertemuan 01 sebesar 9 dengan persentase sebesar 64,29\% dan pertemuan 2 sebesar 10 dengan persentase sebesar 71,43\%. Rendahnya aktivitas guru pada siklus I terjadi karena guru belum sepenuhnya menguasai langkah-langkah dalam RPP sehingga penerapan model pembelajaran inquiry belum terlaksana dengan baik sesuai skenario pembelajaran dalam RPP.

Hasil belajar siswa yang baik tidak hanya dipengaruhi oleh aktivitas siswa itu sendiri tetapi juga ditentukan oleh aktivitas guru dalam menerapkan model pembelajaran yang digunakan. 
Pada pembelajaran yang menggunakan pembelajaran inquirymenjadi lebih menarik karena guru tidak secara monoton tampil dalam posisi sebagai sumber informasi dan penentu kebijakan dalam pembelajaran. Keterlibatan siswa secara penuh dapat dengan mudah ditingkatkan melalui berpikir dan proses pencarian pengetahuan untuk merangsang daya ingat yang lebih lama dan permanen bagi siswa. Hal ini didukung oleh Maryati (2008, p.4) yang menyatakan bahwa dengan cara guru menyajikan serangkaian pertanyaan yang sifatnya menuntun dan menggali maka akan terjadi proses berpikir yang mengaitkan pengetahuan sikap siswa dan pengalamannya dengan pengetahuan yang baru yang sedang dipelajari. Selanjutnya siswa merekontruksi konsep-prinsip-aturan menjadi pengetahuan baru, dengan demikian pengetahuan baru sifatnya tidak hanya diberitahukan tetapi diperoleh sendiri oleh siswa.

Berdasarkan hasil refleksi, pada pelaksanaan tindakan siklus II dilakukan perbaikan terhadap kelemahan dan kekurangan yang ditemui pada siklus I. Guru telah memperbaiki cara menyampaikan konsep materi pembelajaran sehingga merangsang daya nalar dan motivasi siswa untuk belajar lebih baik. Seperti yang dikemukakan oleh Sanjaya (2007, p.176) bahwa memberikan komentar/penjelasan yang baik terhadap materi pelajaran yang akan dipelajari dapat menggugah perhatian siswa sehingga dapat membangun suasana pembelajaran yang optimal.

Berdasarkan hasil observasi pada siklus II, guru dan siswa telah melakukan kegiatan pembelajaran sesuai yang diharapkan dengan mamperbaiki kekurangan-kekurangan yang terjadi pada siklus I. Guru sudah mampu mengorganisasikan waktu dengan baik sehingga penggunaan waktu sudah sesuai dengan yang ditetapkan. Guru sudah mampu memperbaiki cara penyampaian materi yang tepat.Guru sudah melibatkan siswa dalam membuat rangkuman (simpulan) materi pelajaran dan meminta siswa menuliskan simpulan materi pelajaran. Disamping itu, siswa sudah terlihat aktif dan tertib dalam mengikuti kegiatan pembelajaran yang ditandai dengan peningkatan aktivitas siswa pada siklus II.

Adanya peningkatan aktivitas siswa pada siklus II terjadi karena siswa sudah mampu bersosialisasi dengan baik dan bahkan sebagian besar siswa sudah berani mengemukakan pendapat dan pertanyaan yang diberikan oleh guru maupun teman-temannya. Dalam hal ini mereka sudah memberikan sikap positif pada pada saat proses belajar mengajar berlangsung dalam menerapkan metode inquiry.

Berdasarkan hasil evaluasi yang dilakukan pada siklus I, siswa yang memperoleh nilai $\geq 65$ sebanyak 13 orang atau sebesar 59,09\%. Hal ini menunjukkan bahwa standar KKM yang ditetapkan oleh sekolah belum tercapai pada siklus I sehingga peneliti berasumsi bahwa hasil belajar siswa masih dapat ditingkatkan lagi sehingga penelitian dilanjutkan pada siklus II. Pelaksanaan tindakan siklus II menunjukkan peningkatan terhadap hasil belajar siswa dibandingkan siklus I. Hal ini terlihat dari hasil evaluasi yang dilakukan pada siklus II, siswa yang memperoleh nilai $\geq 65$ sebanyak 20 orang atau sebesar 90,91\%. Dengan demikian dapat dikatakan bahwa penerapan metode inquiry tepat digunakan dalam meningkatkan hasil belajar IPA materi daya hantar benda terhadap panas pada siswa kelas VI SD Negeri 1 Tinukari.

Penerapan metode inquiry dapat meningkatkan hasil belajar siswa karena model pembelajaran inquiry memiliki keunggulan yang lebih memicu siswa untuk lebih memahami materi pelajaran yang dipelajari. Seperti yang dikemukakan Kuhne dalam Alberta (2004: 1), Nuriali, W, dkk (2019) menyatakan bahwa menggunakan pembelajaran berdasarkan inquiry dapat membantu para siswa lebih creative, lebih positif, dan lebih mandiri. Menurut Alberta (2004:3), keunggulan-keunggulan yang dimiliki inquiry diantaranya adalah; (1) menfokuskan pada rasa ingin tahu siswa, (2) data dan informasi dibahas, ditentukan, didefinisikan, dan digunakan secara efektif, (3) guru dapat membentuk karakter siswa dengan proses inquiry, (4) siswa menghendel sendiri pembelajaranya, (5) guru memfasilitasi proses pengumpulan dan 
penyajian informasi, (6) Guru dan siswa lebih sering berinteraksi dan lebih aktif selama proses belajar mengajar.

Berdasarkan hasil evaluasi yang diperoleh, menunjukkan bahwa indikator keberhasilan dalam penelitian ini telah tercapai. Dalam hal ini hasil belajar siswa selama proses pembelajaran mencapai kategori baik dan minimal $70 \%$ siswa telah mencapai nilai $\geq$ 65, maka tujuan dalam penelitian ini telah tercapai yaitu dengan penerapan metode inquiry dalam proses pembelajaran IPA, hasil belajar siswa di kelas VI SD Negeri 1 Tinukari dapat ditingkatkan. Dewei dalam Dimyati dan Mudjiono (2002, p.12) bahwa belajar yang baik, dilakukan oleh siswa yang aktif baik secara individual maupun secara kelompok.

Pada penelitian ini, indikator keberhasilan telah tercapai yang terlihat dari pencapaian hasil belajar siswa selama proses pembelajaran sudah sesuai dengan yang diharapkan dengan ketuntasan hasil belajar secara klasikal mencapai 70\%. Hal ini sesuai KKM yang ditetapkan di sekolah bahwa minimal 70\% siswa telah mencapai nilai $\geq 65$.

\section{Simpulan}

Berdasarkan hasil observasi, evaluasi dan pembahasan yang telah dilakukan dapat disimpulkan penerapan metode inkuiri dapat meningkatkan hasil belajar siswa pada materi daya hantar benda terhadap panas pada siswa kelas VI SD Negeri 1 Tinukari. Hal ini dapat dilihat pada peningkatan hasil belajar siswa, pada siklus I rata-rata hasil belajar siswa adalah 63,64 dengan ketuntasan klasikal sebesar 59,09\% sedangkan pada siklus II rata-rata hasil belajar siswa adalah 77,27 dengan ketuntasan klasikal sebesar mencapai 90,91\%.

\section{Referensi}

Alberta (2004). Focus in Inquiry: A Teacher's Guide Ti Implementing Inquiry Based Learning. Edmonton, Canada (Online). http://www.Irc.learning.Gov.ab.ca

Darmawan, Meva, Riyanto M. Taruna, Fitria Akhyar. (2017). Pengaruh Penggunaan Model Inkuiri Terhadap Prestasi Belajar IPA Siswa Kelas V SD. Jurnal Pedagogi Vol 4, No 5. 1-13. http://jurnal.fkip.unila.ac.id/index.php/pedagogi/article/view/11317

Dimyati \& Mudjiono. (2002). Belajar dan Pembelajaran. Jakarta: Rineka Cipta dan Depdikbud.

Hanifah, Ummu. (2017). Perbedaan Efektivitas Antara Penerapan Model Pembelajaran Discovery Dan Inquiry Ditinjau Dari Hasil Belajar IPA Siswa. ejurnalmitrapendidikan, Vol 1, No. 2, April 2017. 92-104. http://www.ejurnalmitrapendidikan.com/index.php/e-jmp/article/view/60

Maryati, I. (2008). Hubungan Antara Kecerdasan Emosi dan Keyakinan Diri (Self-efficacy) Dengan Kreativitas Pada Siswa Akselerasi. Skripsi. Surakarta: Universitas Muhammadiyah Surakarta.

Nuriali, W., Busnawir, B., Samparadja, H., \& Ili, L. (2019). Pengaruh Model Pembelajaran Inkuiri Terbimbing Terhadap Kemampuan Berpikir Kritis Matematika Ditinjau Dari Kemandirian Belajar Siswa SMK. Jurnal Pembelajaran Berpikir Matematika (Journal of Mathematics Thinking Learning), 3(2). 
Retno, Raras Setyo, \& Wachidatul Linda Yuhanna. (2016). Pembelajaran Konsep Dasar IPA Dengan Scientific Inquiry Untuk Meningkatkan Kemampuan Berpikir, Bekerja Dan Bersikap Ilmiah Pada Mahasiswa. Jurnal Pendidikan Biologi Indonesia Volume 2 Nomor 1 Tahun 2016. 1-9. https://core.ac.uk/download/pdf/187672977.pdf

Rosidah, Ani. 2017. Penerapan Model Pembelajaran Kooperatif Snowball Throwing Untuk Meningkatkan Hasil Belajar Siswa Pada Pembelajaran IPS. Jurnal Cakrawala $\begin{array}{lllll}\text { Pendas } & \text { Vol. } & 3 & \text { No.2. } & \text { 29-36. }\end{array}$ http://jurnal.unma.ac.id/index.php/CP/article/download/593/556

Suhada, Hidayati. (2017). Model Pembelajaran Inquiry Dan Kemampuan Berpikir Kritis Terhadap Keterampilan Proses Sains Siswa Kelas V Pada Mata Pelajaran IPA. JPD: Jurnal Pendidikan Dasar Volume 8, Edisi 2, Desember 2017. 13-24. http://journal.unj.ac.id/unj/index.php/jpd/article/view/5315

Suparno. (2008). Keterampilan Dasar Menulis. Jakarta: Universitas Terbuka.

Supriyati \& Mawardi. (2015). Keefektifan Model Pembelajaran Kooperatif Tipe Group Investigation (GI) Dan Inquiry Dalam Pembelajaran IPA Kelas V SD. Scholaria, Vol. 5, No. 2, Mei 2015: 80 - 96. https://ejournal.uksw.edu/scholaria/article/view/19

Ulfah, KR, Anang Santoso, \& Utaya, Sugeng. (2016). Hubungan Motivasi Dengan Hasil Belajar IPS. Jurnal Pendidikan: Teori, Penelitian, dan Pengembangan Volume: 1 Nomor: 8 Bulan Agustus Tahun 2016 Halaman: 1607-1611. http://journal.um.ac.id/index.php/jptpp/article/view/6678/2885

Wina Sanjaya. (2007). Strategi Pembelajaran Berorientasi Standar Proses Pendidikan. Jakarta: Kencana Prenada Media Group. 